\title{
The variation in free 25-hydroxy vitamin D and vitamin D-binding protein with season and vitamin D status
}

\author{
Göran Oleröd', Lillemor Mattsson Hultén ${ }^{2}$, Ola Hammarsten ${ }^{1}$ and Eva Klingberg ${ }^{3}$ \\ 'Department of Clinical Chemistry and Transfusion Medicine, Sahlgrenska Academy at the University of \\ Gothenburg, Gothenburg, Sweden \\ ${ }^{2}$ Department of Clinical Chemistry, Sahlgrenska University Hospital, Gothenburg, Sweden \\ ${ }^{3}$ Department of Rheumatology and Inflammation Research, Sahlgrenska Academy at the University of \\ Gothenburg, Gothenburg, Sweden
}

\begin{abstract}
Purpose: Serum 25-hydroxy vitamin D [25(OH)D] varies greatly with season at northern latitudes. The purpose of this study was to determine if the seasonal variations in serum total 25(OH)D are followed by a concomitant variation in free 25(OH)D or if the variation is damped by alterations in the binding capacity of DBP.

Methods: Serum was collected from 540 healthy blood donors (60\% men; mean age $41 \pm 13$ years) during 12 months and analyzed for total 25(OH)D, directly measured free $25(\mathrm{OH}) \mathrm{D}$, vitamin D-binding protein (DBP) and albumin. Calculated free 25(OH)D was estimated.

Results: The UV-B radiation during the sampling month was positively correlated with the serum levels of total 25(OH)D $(r=0.355, P<0.001)$, directly measured free $(r=0.336$, $P<0.001)$ and calculated free 25(OH)D $(r=0.275, P<0.001)$, but not with DBP and albumin. The percentage of free $25(\mathrm{OH}) \mathrm{D}$ was higher during the winter months than that during the summer months $(0.020 \pm 0.005 \%$ vs $0.019 \pm 0.004 \% ; P=0.007)$ and higher in participants with a serum 25(OH)D below $25 \mathrm{nmol} / \mathrm{L}$ than that in participants with a serum $25(\mathrm{OH}) \mathrm{D}$ above $75 \mathrm{nmol} / \mathrm{L}(0.031 \pm 0.007 \%$ vs $0.017 \pm 0.003 \% ; P<0.001)$. iPTH was correlated with directly measured free 25(OH)D $(r=-0.226 ; P<0.001)$, but only weakly with calculated free 25(OH)D $(r=-0.095 ; P=0.027)$.

Conclusions: Directly measured free serum $25(\mathrm{OH}) \mathrm{D}$ was highly correlated with total serum 25(OH)D and followed the same seasonal variation, whereas the serum concentrations of DBP and albumin were stable. The fluctuation in free 25(OH)D was only marginally damped with an increase in the percentage of free $25(\mathrm{OH}) \mathrm{D}$ during the winter months and in participants with vitamin $D$ deficiency.
\end{abstract}

\author{
Correspondence \\ should be addressed \\ to E Klingberg \\ Email \\ Eva.Klingberg@vgregion.se
}

Endocrine Connections (2017) 6, 111-120

\section{Introduction}

Vitamin D is essential for the calcium homeostasis and bone health and also of importance for the immune function, muscles and the cardiovascular system. Vitamin D3 is mainly produced in the skin after ultraviolet radiation, but smaller amounts of vitamin D2 and D3 are

\section{Key Words}

- free 25-hydroxy vitamin D

- vitamin D-binding protein

- 25-hydroxy vitamin D

- vitamin $D$ deficiency

- parathyroid hormone 
To assess a persons' vitamin D status, 25(OH)D is the metabolite that is measured in serum (1). Being a highly hydrophobic molecule, most circulating $25(\mathrm{OH}) \mathrm{D}$ is bound to either vitamin D-binding protein (DBP) $(88 \%)$ or albumin (12\%) and only a small fraction, less than $1 \%$, circulates in a free unbound form (2). 25(OH)D binds with high affinity to DBP, but with lower affinity to albumin. The albumin-bound fraction of $25(\mathrm{OH}) \mathrm{D}$ plus free fraction has therefore been referred to as the bioavailable fraction of $25(\mathrm{OH}) \mathrm{D}(3,4)$.

DBP is a $52-58 \mathrm{kDa}$ glucoprotein produced in the liver, belonging to the albuminoid superfamily (5). First of all DBP is a carrier protein for the circulating vitamin D metabolites, but other roles for the protein have been described, such as the binding of fatty acids and endotoxins, chemotactic effects on neutrophil granulocytes, activating of macrophages and the sequestration of actin upon tissue damage (6). As the serum concentration of DBP is 20-fold higher than that of the vitamin D metabolites, only $2-5 \%$ of the circulating DBP is occupied by the vitamin D metabolites $[25(\mathrm{OH}) \mathrm{D}$ and $\left.1,25(\mathrm{OH})_{2} \mathrm{D}\right]$. DBP prolongs the half-life of $25(\mathrm{OH}) \mathrm{D}$, can act as a reservoir for $25(\mathrm{OH}) \mathrm{D}$ in situations of deficiency and also protect against vitamin D intoxication (7).

The concentration of free $25(\mathrm{OH}) \mathrm{D}$ can either be calculated using a formula, which includes the concentrations of DBP and albumin as described herein, or it can be directly measured (8). A problem with the calculation of the free concentration is that the DBP levels are not constant, but can vary in conditions such as pregnancy, liver cirrhosis, kidney disease and malnutrition (9). The concentrations of DBP and its' binding affinity for the vitamin $\mathrm{D}$ metabolites also vary among different populations depending on the polymorphism in the expression of the three different DBP isotypes $(6,10)$. Lower DBP concentrations have been observed in African-Americans compared with European-Americans when DBP was measured with an immunoassay using monoclonal DBP antibodies, but not when measured with a mass spectrometry or immunoassays using polyclonal DBP antibodies $(11,12,13,14,15)$.

In a previous study, we analyzed serum $25(\mathrm{OH}) \mathrm{D}$ in a cohort of blood donors during 12 months and found that $50 \%$ of the participants had a $25(\mathrm{OH}) \mathrm{D}$ below $50 \mathrm{nmol} / \mathrm{L}$ during $50 \%$ of the year and that the levels varied greatly with season (16).

The primary aim of the present study was to determine if the seasonal variations observed in total $25(\mathrm{OH}) \mathrm{D}$ in serum is followed by a concomitant variation in free $25(\mathrm{OH}) \mathrm{D}$ or if the variation is damped by alterations in the binding capacity of DBP. We also wanted to compare the concentrations of directly measured with calculated free $25(\mathrm{OH}) \mathrm{D}$ and explore the associations between serum DBP and free $25(\mathrm{OH}) \mathrm{D}$ with demographic and life styleassociated parameters.

\section{Methods}

\section{Healthy blood donors}

Healthy blood donors resident in Gothenburg, Sweden $\left(57^{\circ} 41^{\prime} \mathrm{N}, 11^{\circ} 59^{\prime} \mathrm{E}\right)$ were invited to participate in the study when giving blood. Totally 540 blood donors were included, 40-60 in the middle of each month during a whole year. All blood samples were collected in the morning between 08:00 and 11:00 h.

Informed consent was obtained from all individual participants included in the study. The study was approved by the Regional Ethics Committee in Gothenburg and carried out in accordance with the Helsinki declaration.

All blood donors stated that they were in full physical health and answered questionnaires regarding medication, smoking habits, physical activity, sunbed use and sun holidays during the previous month. A sun holiday was defined as a journey to a location south of the latitude $43^{\circ} \mathrm{N}$. Body weight and height were measured, and body mass index (BMI) was calculated.

\section{Ethical approval}

All procedures performed in the study involving human participants were in accordance with the ethical standards of the institutional and/or national research committee and with the 1964 Helsinki Declaration and its later amendments or comparable ethical standards.

\section{Laboratory analyses}

The serum samples were frozen at $-80^{\circ} \mathrm{C}$ immediately after collection.

Serum 25(OH)D (both D2 and D3) was analyzed with chemiluminescence immunoassay (CLIA) on a LIAISON instrument (DiaSorin Inc, Stillwater, MN, USA). The total coefficient of variance $(\mathrm{CV})$ for serum $25(\mathrm{OH}) \mathrm{D}$ was $5-6 \%$, with the highest variance in the lowest test range, and the limit of quantification (LoQ) was $12.5 \mathrm{nmol} / \mathrm{L}$ at a CV of $8 \%$.

The free $25(\mathrm{OH}) \mathrm{D}$ concentration in serum was measured with enzyme-linked immunosorbent assay (ELISA) using a commercial kit (Future Diagnostics Solutions, Wijchen, The Netherlands), hereafter, named
This work is licensed under a Creative Commons Attribution-NonCommercial-NoDerivs 4.0 International License. 
directly measured free $25(\mathrm{OH}) \mathrm{D}$. The analysis at the laboratory showed a total CV of $7.6 \%$ at a level of $4 \mathrm{pg} / \mathrm{mL}$ and a CV of $18 \%$ at $1.8 \mathrm{pg} / \mathrm{mL}$, which was used as LoQ. Only two patients had a serum-free $25(\mathrm{OH}) \mathrm{D}$ below LoQ. The concentration of free $25(\mathrm{OH}) \mathrm{D}$ in serum was measured in $\mathrm{pg} / \mathrm{mL}$, but converted to $\mathrm{pmol} / \mathrm{L}$ by using the formula $1 \mathrm{pg} / \mathrm{mL}=2.5 \mathrm{pmol} / \mathrm{L}$.

Serum DBP was measured with a monoclonal ELISA (R\&D Systems). Our analysis showed a total CV of 7.4\% at the level of $268 \mathrm{mg} / \mathrm{L}$ and a CV of $17.6 \%$ at $1.3 \mathrm{mg} / \mathrm{L}$, which was to be used as LoQ.

Serum intact parathyroid hormone (iPTH) was analyzed with CLIA on an Abbott ARCHITECT instrument (Abbott Diagnostics Division) and serum 1,25(OH) ${ }_{2} \mathrm{D}$ was analyzed on an IDS-iSYS instrument (Immunodiagnostic Systems Holdings, Boldon, UK). The serum levels of albumin, highly sensitive C-reactive protein (hsCRP), calcium, phosphate, creatinine, alanine aminotransferase (ALT), sexual hormone-binding globulin (SHBG), estradiol and testosterone were analyzed with standard laboratory techniques on a Cobas instrument (Roche Molecular Diagnostics)

\section{The calculation of free 25(OH)D and bioavailable 25(OH)D in serum}

Free $25(\mathrm{OH}) \mathrm{D}$ was calculated using the formula described by Bikle et al. (8):

Calculated free $25(\mathrm{OH}) \mathrm{D}$

$$
=\frac{\text { Total } 25(\mathrm{OH}) \mathrm{D}}{1+\left(6 \times 10^{5} \times[\text { Albumin }]\right)+\left(7 \times 10^{8} \times[\mathrm{DBP}]\right)}
$$

Bioavailable 25 $(\mathrm{OH}) \mathrm{D}$

$$
\begin{aligned}
= & \left(6 \times 10^{5} \times[\text { Albumin }]+1\right) \\
& \times \text { calculated free } 25(\mathrm{OH}) \mathrm{D}
\end{aligned}
$$

[Albumin] = serum albumin in $\mathrm{g} / \mathrm{L} \div 66,430 \mathrm{~g} / \mathrm{mol}$ $[\mathrm{DBP}]=$ serum DBP in $\mathrm{g} / \mathrm{L} \div 58,000 \mathrm{~g} / \mathrm{mol}$

The percentage of free $25(\mathrm{OH}) \mathrm{D}=\frac{\text { Free } 25(\mathrm{OH}) \mathrm{D}}{\operatorname{Total} 25(\mathrm{OH}) \mathrm{D}}$

\section{Estimated UVB irradiation}

Monthly sums of Commission Internationale de l'E' clairage (CIE)-weighted UV radiation $\left(\mathrm{Wh} / \mathrm{m}^{2}\right)$, which mimics the erythemal effect of UV radiation, were calculated for Gothenburg $\left(57^{\circ} 41^{\prime} \mathrm{N}, 11^{\circ} 59^{\prime} \mathrm{E}\right)$ for each month during a year using the Swedish Meteorological and Hydrological Institute's (SMHI) solar radiation model STRÅNG (http://strang.smhi.se/).

\section{Statistical analyses}

Statistical analyses were made using SPSS Statistics 23.0 (SPSS). Descriptive statistics are presented as mean \pm S.D. In comparisons between groups, the independent samples $t$-test was used for continuous variables and the chi-square test for categorical variables. Correlations were calculated using Pearson correlation ( $r$ ) for all parameters, except for hsCRP where Spearman correlation $\left(r_{\mathrm{S}}\right)$ was used due the skewed distribution of the parameter. All tests were two-tailed, and $P<0.05$ was considered statistically significant. Linear regression with a stepwise method was run with serum DBP as outcome. Covariates were the parameters significantly associated with serum DBP in the first analyses. The results from the linear regression are presented as unstandardized coefficients $(B)$ and standard error (S.E.).

\section{Results}

\section{Healthy blood doors}

The characteristics of the 540 healthy blood donors are presented in Table 1.

\section{The seasonal variation in vitamin D metabolites}

The serum levels of free $25(\mathrm{OH}) \mathrm{D}$, both directly measured and calculated and bioavailable $25(\mathrm{OH}) \mathrm{D}$ all followed the seasonal variation of total serum $25(\mathrm{OH}) \mathrm{D}$, with a peak during the summer months and a low point during the winter months. There was no seasonal variation in serum DBP, serum albumin, serum calcium or serum $1,25(\mathrm{OH})_{2} \mathrm{D}$. Serum phosphate also followed the seasonal variation of total $25(\mathrm{OH}) \mathrm{D}$, whereas serum iPTH demonstrated an inverse pattern with a low point during the summer and a peak during the winter (Fig. 1).

The CIE-weighted UV radiation during the sampling month was positively correlated with the serum levels of total $25(\mathrm{OH}) \mathrm{D}(r=0.355, P<0.001)$, directly measured free 25(OH)D $(r=0.336, P<0.001)$, calculated free $25(\mathrm{OH}) \mathrm{D}$ $(r=0.275, P<0.001)$ and bioavailable 25(OH)D $(r=0.275$, $P<0.001)$, but not with the serum levels of DBP $(r=-0.011$, 
Table 1 The characteristics of the 540 blood donors included in the study.

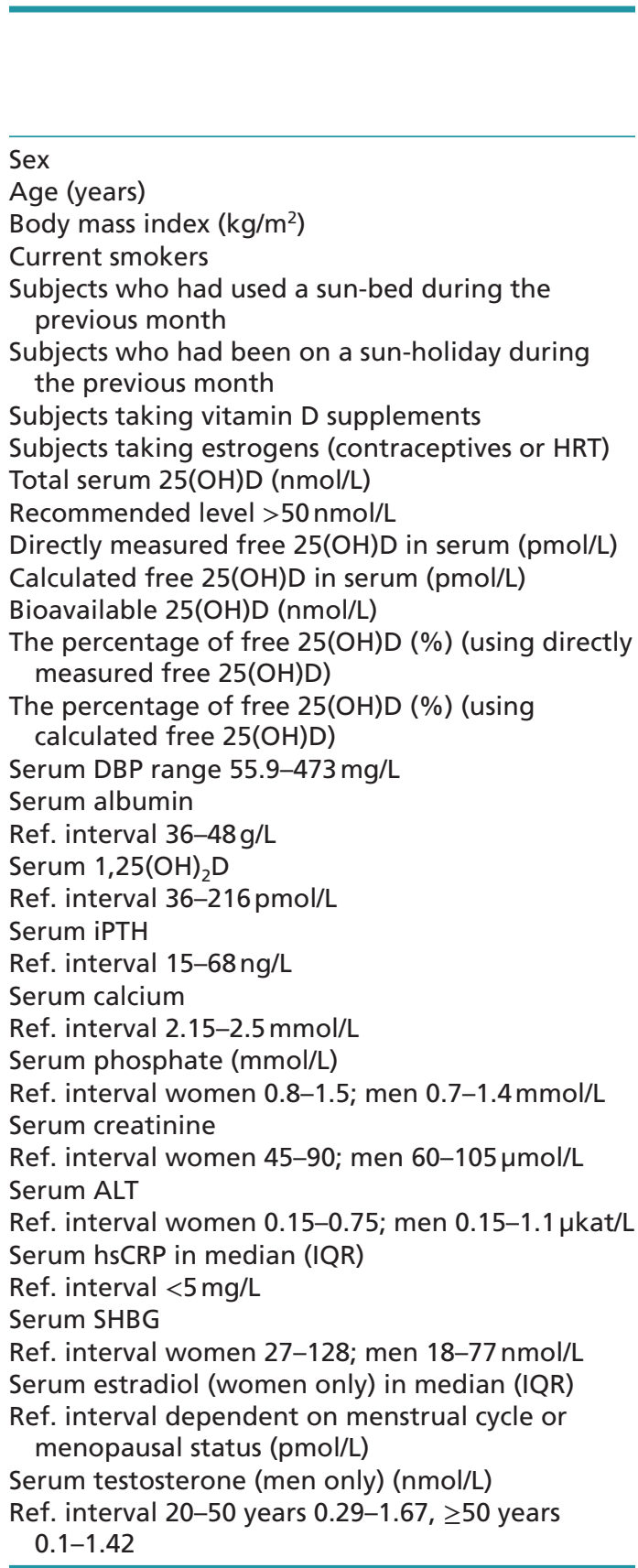

\begin{tabular}{c}
\hline All \\
\hline$N(\%)$ \\
\hline Mean \pm s.D. \\
\hline 540 \\
$40.9 \pm 13.0$ \\
$24.8 \pm 4.0$ \\
$24(4.4)$ \\
$23(4.3)$ \\
$36(6.7)$
\end{tabular}

$36(6.7)$

$50(9.3)$

$62.8 \pm 26.3$

$11.5 \pm 4.3$

$19.7 \pm 10.7$

$7.4 \pm 4.1$

$0.019 \pm 0.004$

$0.032 \pm 0.013$

$253.1 \pm 78.9$

$41.5 \pm 4.4$

$116.6 \pm 42.5$

$44.0 \pm 18.6$

$2.4 \pm 0.13$

$1.3 \pm 0.4$

$81.2 \pm 14.6$

$0.5 \pm 0.4$

$0.64(0.32-1.2)$

$60.6 \pm 40.9$

\begin{tabular}{c}
\hline Women \\
\hline$N(\%)$ \\
\hline Mean \pm S.D. \\
\hline $215(39.8)$ \\
$38.9 \pm 12.8$ \\
$24.2 \pm 3.4$ \\
$9(4.2)$ \\
$17(7.9)$ \\
$15(7.0)$
\end{tabular}

27 (12.6)

$24(11.2)$

$65.6 \pm 25.3$

$11.7 \pm 4.2$

$19.8 \pm 9.7$

$7.2 \pm 3.6$

$0.018 \pm 0.004$

$0.031 \pm 0.010$

$265.4 \pm 87.8$

$40.3 \pm 3.8$

$121.3 \pm 46.1$

$45.0 \pm 19.4$

$2.4 \pm 0.12$

$1.4 \pm 0.4$

$71.8+10.8$

$0.4 \pm 0.4$

$0.63(0.33-1.28)$

$85.7 \pm 51.8$

\begin{tabular}{c} 
Men \\
\hline$N(\%)$ \\
\hline Mean \pm s.D. \\
\hline $325(60.2)$ \\
$42.3 \pm 13.1$ \\
$25.2 \pm 4.3$ \\
$15(4.6)$ \\
$6(1.8)$
\end{tabular}

21 (6.5)

$23(7.1)$

$61.0 \pm 26.8$

$11.4 \pm 4.4$

$19.6 \pm 11.3$

$7.5 \pm 4.4$

$0.020 \pm 0.044$

$0.033 \pm 0.014$

$244.9 \pm 71.5$

$42.2 \pm 4.7$

$113.5 \pm 39.6$

$43.4 \pm 18.1$

$2.4 \pm 0.13$

$1.3 \pm 0.4$

$87.5 \pm 13.3$

$0.5 \pm 0.3$

$0.65(0.31-1.15)$

$44.0 \pm 17.7$

$102.5(18.3-277.8)$

1,25(OH) $)_{2}$, 1,25-dihydroxy vitamin D; 25(OH)D, 25-hydroxy vitamin D; ALT, alanine aminotransferase; BMI, body mass index; DBP, vitamin D binding protein; HRT, hormone replacement therapy; hsCRP, highly sensitive c-reactive protein; iPTH, intact parathyroid hormone; IQR, interquartile range; SHBG, sexual hormone binding globulin.

$P=0.840)$, albumin $(r=0.045, P=0.292)$ or $1,25(\mathrm{OH})_{2} \mathrm{D}$ $(r=0.071, P=0.104)$.

The monthly serum concentrations of total $25(\mathrm{OH})$ $\mathrm{D}$, measured free $25(\mathrm{OH}) \mathrm{D}$, calculated free $25(\mathrm{OH}) \mathrm{D}$, bioavailable $25(\mathrm{OH}) \mathrm{D}, 1,25(\mathrm{OH})_{2} \mathrm{D}$ and $\mathrm{DBP}$ are shown in Fig. 1 and in Table 2.

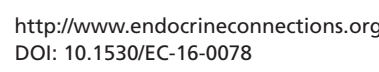

\section{Directly measured free 25(OH)D compared with calculated free 25(OH)D}

The serum levels of directly measured free $25(\mathrm{OH}) \mathrm{D} \quad(\mathrm{mean} \pm$ S.D. $11.5 \pm 4.3 \mathrm{pmol} / \mathrm{L}$ corresponding to $4.6 \pm 1.8 \mathrm{pg} / \mathrm{mL}$ ) was significantly lower than the serum levels of calculated free $25(\mathrm{OH}) \mathrm{D}$ (mean \pm s.D.

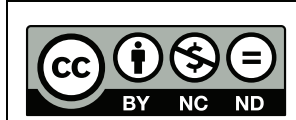

This work is licensed under a Creative Commons Attribution-NonCommercial-NoDerivs 4.0 International License. 
A
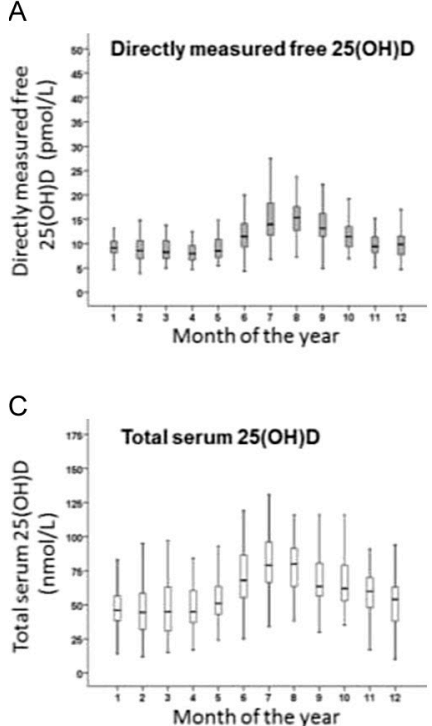
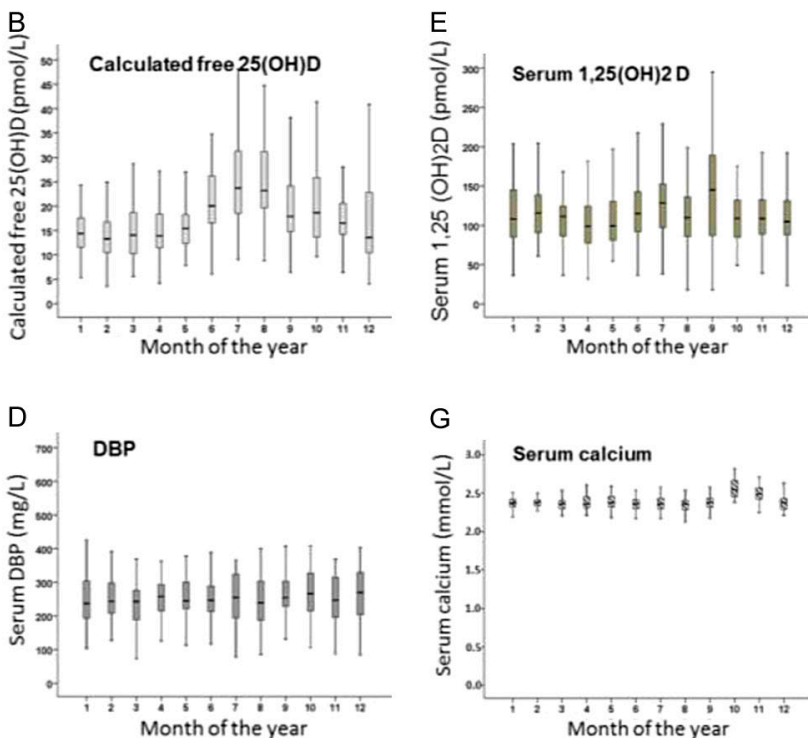

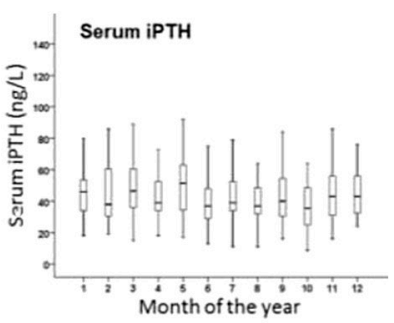

G

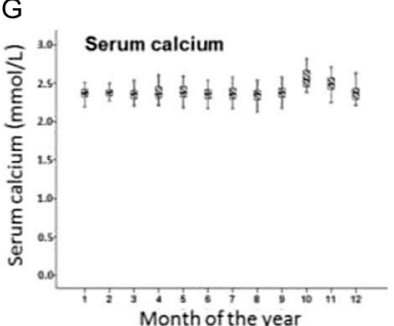

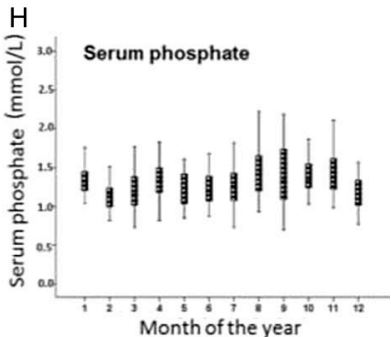

Figure 1

Boxplot diagram showing the variation in the vitamin $D$ metabolites over the months of the year. (A) Directly measured free 25(OH)D. (B) Calculated free 25(OH)D. (C) Total serum 25(OH)D. (D) Vitamin D-binding protein. (E) Serum 1,25(OH) 2 D. Regarding September the result is uncertain due to missing data from several of the controls. (F) Serum iPTH. (G) Serum calcium. (H) Serum phosphate.

$19.7 \pm 10.7 \mathrm{pmol} / \mathrm{L}$ corresponding to $7.9 \pm 4.3 \mathrm{pg} / \mathrm{mL}$, $P<0.001)$. The correlation between directly measured and calculated free $25(\mathrm{OH}) \mathrm{D}$ was $r=0.695, P<0.001$.

The directly measured 25(OH)D showed a closer relationship with total serum 25(OH)D $(r=0.880$, $P<0.001)$ than did the calculated free $25(\mathrm{OH}) \mathrm{D}(r=0.670$, $P<0.001)$ (Fig. 2). In addition, directly measured free $25(\mathrm{OH}) \mathrm{D}$ showed a stronger correlation with serum
iPTH $(r=-0.226 ; P<0.001)$ than calculated free 25(OH)D $(r=-0.095 ; P=0.027)$, comparable with the association between total 25(OH)D and iPTH $(r=-0.257 ; P<0.001)$.

\section{The percentage of free 25(OH)D in serum}

The percentage of free $25(\mathrm{OH}) \mathrm{D}$, representing the fraction of total $25(\mathrm{OH}) \mathrm{D}$, which circulates in a free

Table 2 The monthly serum variation in total 25(OH)D, directly measured free 25(OH)D, calculated free 25(OH)D, bioavailable 25(OH)D, 1,25(OH) 2 D and DBP.

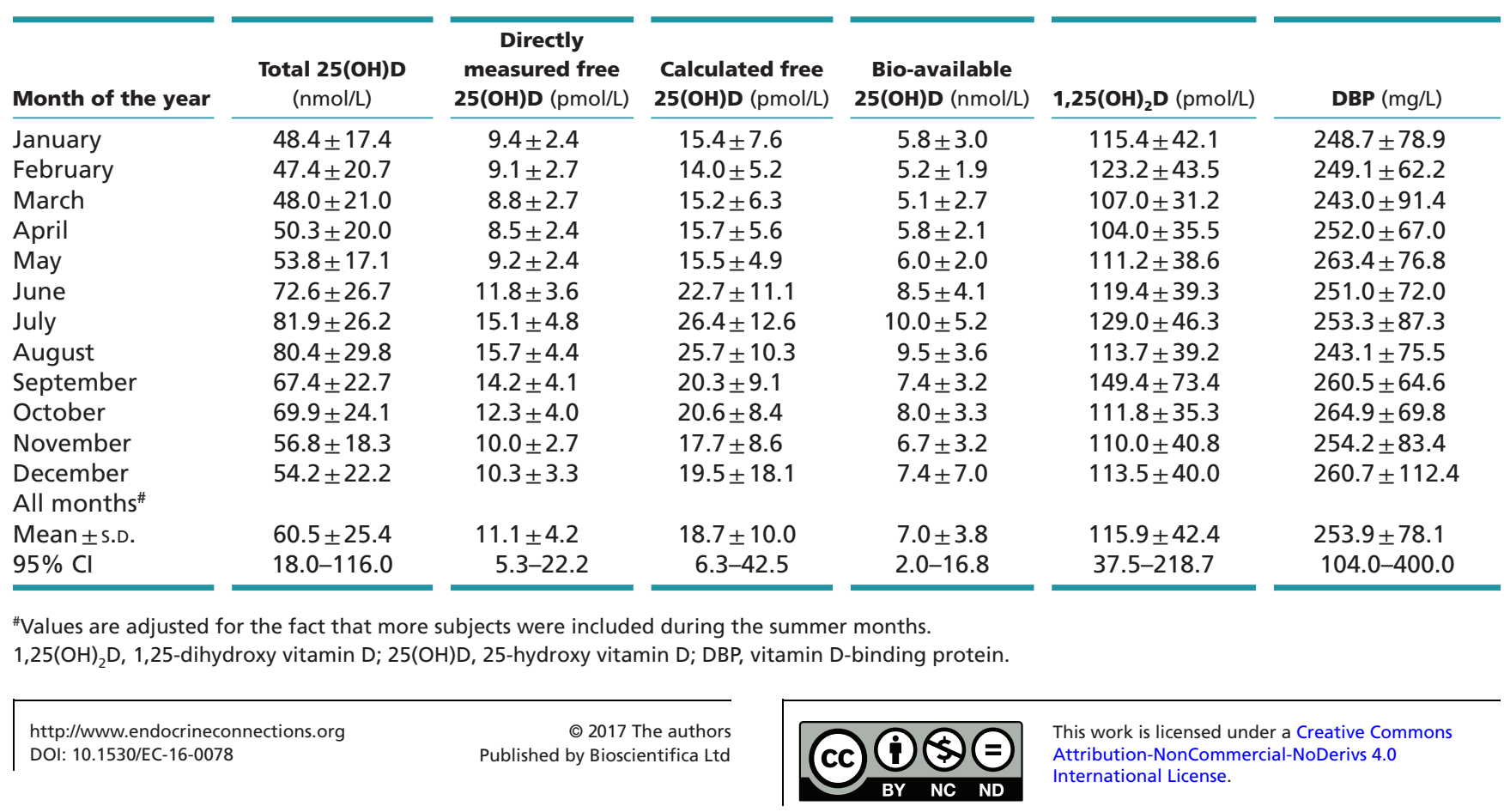


A

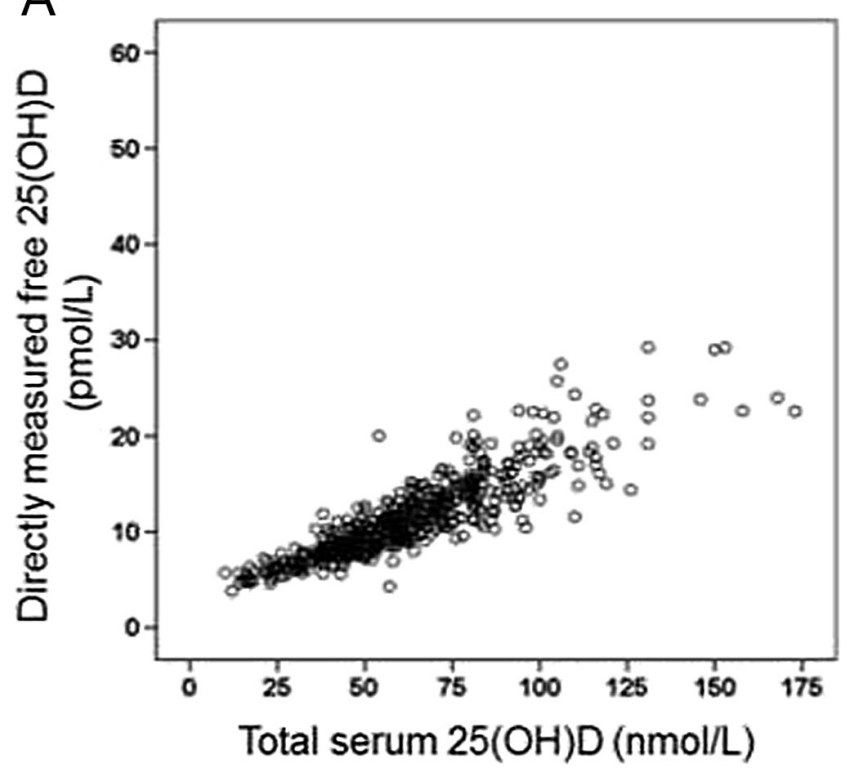

B

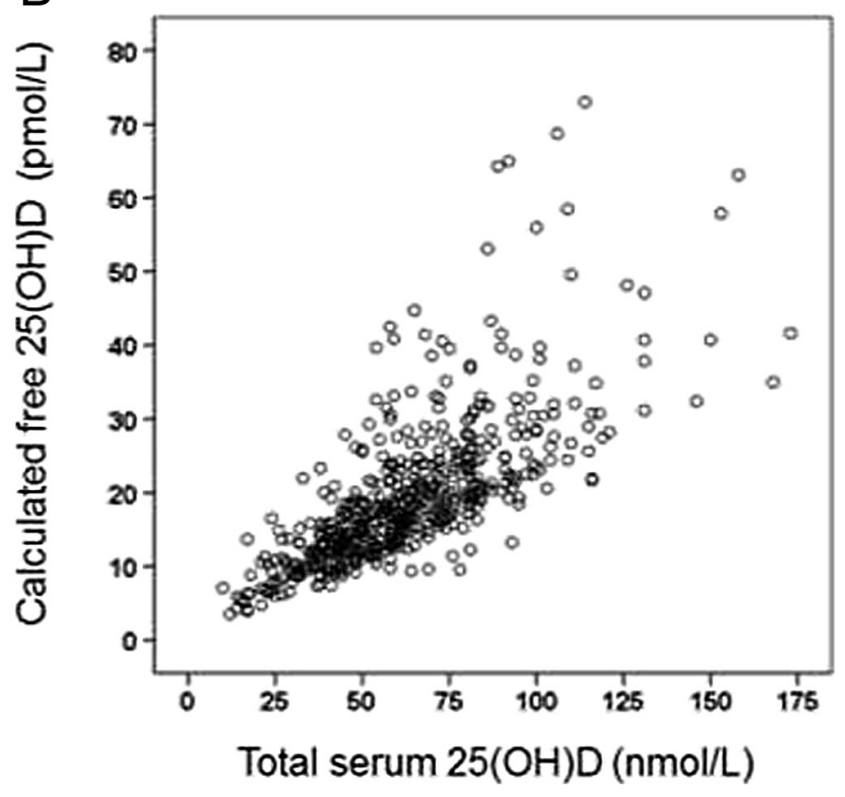

Figure 2

Scatter diagram showing the relation between total 25(OH)D and (A) directly measured free 25(OH)D and (B) calculated free 25(OH)D. (In Fig. 2A, two study subjects had a directly measured free $25(\mathrm{OH}) \mathrm{D}$ below the limit of quantification $1.8 \mathrm{pg} / \mathrm{mL}=4.5 \mathrm{pmol} / \mathrm{L}$.)

unbound form, was calculated using the formula: (directly measured serum free $25(\mathrm{OH}) \mathrm{D} /$ serum total $25(\mathrm{OH}) \mathrm{D})$. The percentage of free $25(\mathrm{OH}) \mathrm{D}$ was $0.019 \pm 0.004 \%$ in this cohort.

The percentage of free $25(\mathrm{OH}) \mathrm{D}$ was negatively correlated with total serum $25(\mathrm{OH}) \mathrm{D} ; r=-0.474, P<0.001$ (Fig. 3A). Thus, the percentage of free $25(\mathrm{OH}) \mathrm{D}$ was

http://www.endocrineconnections.org DOI: 10.1530/EC-16-0078

2017 The authors Published by Bioscientifica Ltd
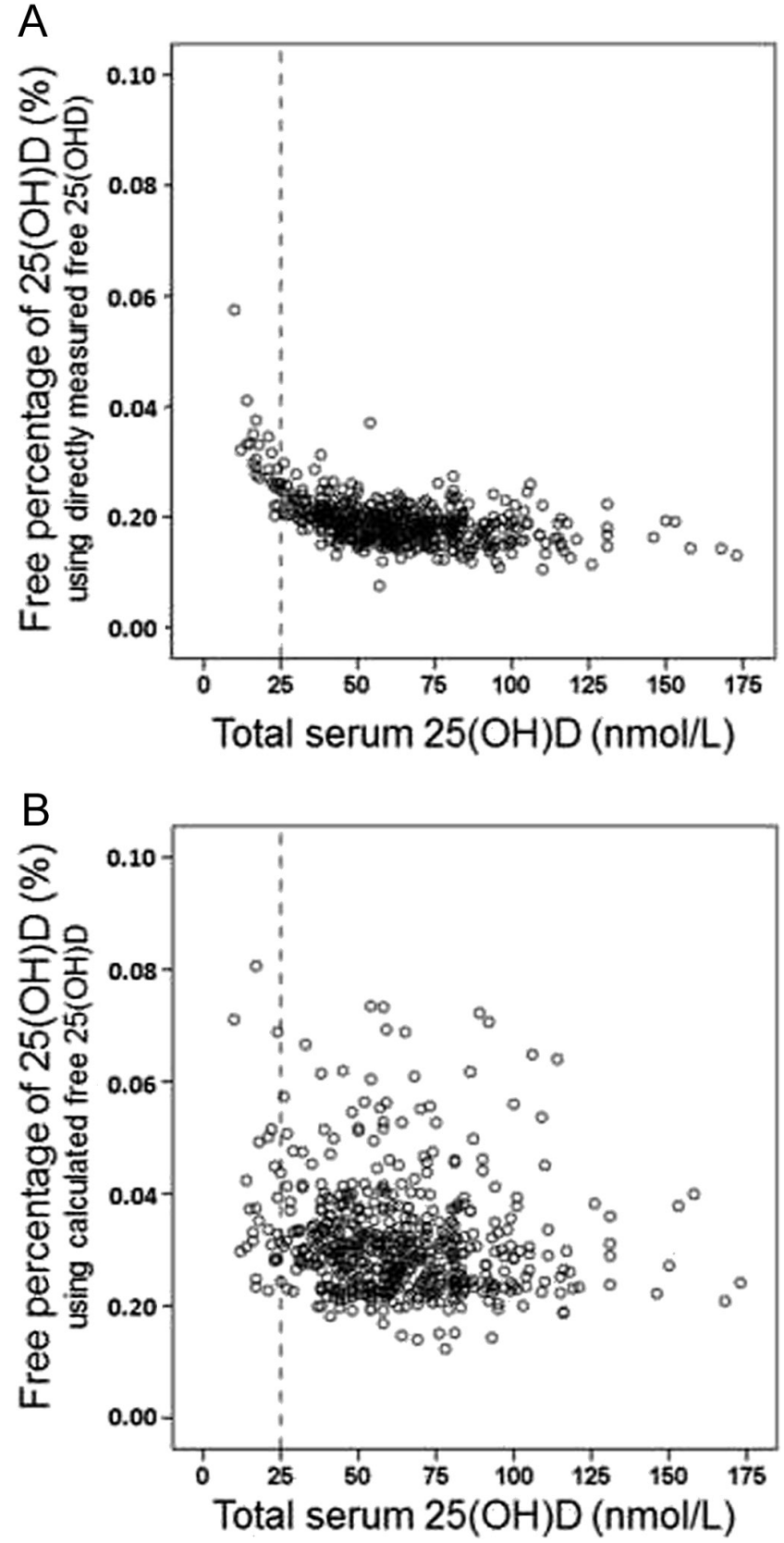

Figure 3

Scatter diagram showing the relation between total serum 25(OH)D and $(A)$ directly measured free fraction of $25(\mathrm{OH}) \mathrm{D}$ in serum, with an increase in the free fraction in participants with a total serum $25(\mathrm{OH})$ $D$ below $25 \mathrm{nmol} / \mathrm{L}$ and (B) calculated free fraction of 25(OH)D in serum.

higher during the winter months than that during the summer months $(0.020 \pm 0.005 \%$ vs $0.019 \pm 0.004 \%$; $P=0.007)$ and higher in participants with a serum $25(\mathrm{OH}) \mathrm{D}$ below $25 \mathrm{nmol} / \mathrm{L}$ than that in participants with a serum $25(\mathrm{OH}) \mathrm{D}$ above $75 \mathrm{nmol} / \mathrm{L}(0.031 \pm 0.007 \%$ vs $0.017 \pm 0.003 \% ; P<0.001$ ) (Table 3 ). 
Table 3 The difference in the serum concentration of free 25(OH)D and the free fractions between participants with vitamin $D$ deficiency vs vitamin D sufficiency.

\begin{tabular}{|c|c|c|c|}
\hline & \multirow{2}{*}{$\begin{array}{c}\text { Vitamin D deficiency (total } \\
\text { serum } 25(\mathrm{OH}) \mathrm{D}<25 \mathrm{nmol} / \mathrm{L})\end{array}$} & \multirow{3}{*}{$\begin{array}{c}\text { Vitamin D Sufficiency (total } \\
\text { serum } 25(\mathrm{OH}) \mathrm{D} \geq 75 \mathrm{nmol} / \mathrm{L}) \\
N=152\end{array}$} & \multirow{3}{*}{$\begin{array}{l}\text { Significance } \\
P \text {-value }\end{array}$} \\
\hline & & & \\
\hline & Mean \pm S.D. & & \\
\hline Directly measured free $25(\mathrm{OH}) \mathrm{D}$ in serum $(\mathrm{pmol} / \mathrm{L})$ & $5.6 \pm 0.82$ & $16.4 \pm 4.1$ & $<0.001$ \\
\hline Calculated free $25(\mathrm{OH}) \mathrm{D}$ in serum $(\mathrm{pmol} / \mathrm{L})$ & $7.4 \pm 3.1$ & $28.3 \pm 11.4$ & $<0.001$ \\
\hline $\begin{array}{l}\text { The percentage of free 25(OH)D (\%) (using directly } \\
\text { measured free } 25 \mathrm{OHD} \text { ) }\end{array}$ & $0.031 \pm 0.007$ & $0.017 \pm 0.003$ & $<0.001$ \\
\hline $\begin{array}{l}\text { The percentage of free } 25(\mathrm{OH}) \mathrm{D}(\%) \text { (using calculated free } \\
25(\mathrm{OH}) \mathrm{D})\end{array}$ & $0.039 \pm 0.015$ & $0.030 \pm 0.010$ & 0.005 \\
\hline Serum DBP (mg/L) & $203.4 \pm 70.6$ & $272.0 \pm 86.0$ & $<0.001$ \\
\hline Serum albumin $(\mathrm{g} / \mathrm{L})$ & $41.9 \pm 3.2$ & $41.5 \pm 4.3$ & 0.646 \\
\hline Serum $1,25(\mathrm{OH})_{2} \mathrm{D}(\mathrm{pmol} / \mathrm{L})$ & $80.5 \pm 25.5$ & $129.2 \pm 47.4$ & $<0.001$ \\
\hline Serum iPTH (ng/L) & $62.0 \pm 32.4$ & $38.7 \pm 17.0$ & 0.002 \\
\hline
\end{tabular}

1,25(OH) 2 D, 1,25-dihydroxy vitamin $\mathrm{D} ; 25(\mathrm{OH}) \mathrm{D}, 25$-hydroxy vitamin $\mathrm{D}$; DBP, vitamin $\mathrm{D}$ binding protein; iPTH, intact parathyroid hormone.

The percentage of free $25(\mathrm{OH}) \mathrm{D}$ was also positively associated with BMI $(r=0.206, P<0.001)$.

When using calculated free $25(\mathrm{OH}) \mathrm{D}$ in the formula for the percentage of free $25(\mathrm{OH}) \mathrm{D}$ (calculated serum free $25(\mathrm{OH}) \mathrm{D} /$ serum total $25(\mathrm{OH}) \mathrm{D})$ the free percentage was significantly larger $(0.032 \pm 0.013 \% ; P \leq 0.001)$, as expected. The correlation with total serum $25(\mathrm{OH}) \mathrm{D}$ was also weaker $(r=-0.134, P=0.002)$ and the value of the percentage of free $25(\mathrm{OH}) \mathrm{D}$ of calculated free $25(\mathrm{OH}) \mathrm{D}$ increased less in vitamin D deficiency (Fig. 3B and Table 3).

\section{Directly measured free 25(OH)D in serum in relation to demographics and lifestyle-related parameters}

Directly measured free $25(\mathrm{OH}) \mathrm{D}$ was equally distributed over sex, age and smoking status, but negatively correlated with BMI $(r=-0.175, P<0.001)$. The higher levels of total $25(\mathrm{OH}) \mathrm{D}$ in serum among the women could be due to their higher use of sun beds, as explained previously (16).

In addition, directly measured free $25(\mathrm{OH}) \mathrm{D}$ was higher in sun bed users compared with that in nonusers $(13.7 \pm 4.8$ vs $11.4 \pm 4.3 \mathrm{pmol} / \mathrm{L} ; P=0.014)$ and in participants who had been on a sun holiday during the last month $(15.9 \pm 5.9$ vs $11.2 \pm 4.0 ; P<0.001)$.

\section{Serum DBP in relation to demographics, vitamin D metabolites and other laboratory parameters}

The associations between DBP and demographic variables, vitamin D metabolites and other laboratory parameters are shown in Table 4. (c) 2017 The authors

http://www.endocrineconnections.org DOI: 10.1530/EC-16-0078
Serum DBP was higher in women than that in men. The $95 \%$ confidence interval (CI) was $102-517 \mathrm{mg} / \mathrm{L}$ for the women and 92-382 mg/L for the men. Premenopausal women had a tendency to have higher serum DBP than postmenopausal women, but the difference did not reach the level of significance. Among women under age 50 years, the users of oral contraceptives had significantly higher serum DBP than non-users. The users of oral contraceptives also had significantly higher serum total $25(\mathrm{OH}) \mathrm{D} \quad(87.5 \pm 39.3$ vs $64.9 \pm 22.7 ; \quad P=0.017)$, but lower free percentage of $25(\mathrm{OH}) \mathrm{D}(0.017 \pm 0.003 \%$ vs $0.019 \pm 0.004 \% ; P=0.015)$ compared with non-users, whereas the difference in directly measured free $25(\mathrm{OH}) \mathrm{D}$ in serum did not reach level of significance $(14.3 \pm 6.1$ vs $11.8 \pm 4.1 ; P=0.076)$, maybe due to the relatively small number of cases.

Further serum DBP was positively correlated with SHBG and hsCRP and weakly negatively correlated with BMI.

Serum DBP was also positively correlated with serum levels of total $25(\mathrm{OH}) \mathrm{D}$ and negatively correlated with calculated free $25(\mathrm{OH}) \mathrm{D})$ and $\mathrm{PTH}$, whereas no correlation with directly measured free $25(\mathrm{OH}) \mathrm{D}$ was found.

Linear regression was run with serum DBP as outcome and the following parameters as covariates: sex, age, BMI, use of contraceptives and the serum levels of $25(\mathrm{OH}) \mathrm{D}$, $1,25(\mathrm{OH})_{2} \mathrm{D}$, iPTH, SHBG, testosterone and estradiol. In this analysis, serum DBP remained independently and significantly associated with serum SHBG $(B=0.472$, S.E. $=13.792, P<0.001)$, total serum 25(OH)D $(B=0.395$, S.E. $=0.129, P=0.002)$ and iPTH $(B=-0.370$, S.E. $=0.183$, $P=0.043)$. 
Table 4 The association between DBP and demographics, vitamin D metabolites and other laboratory parameters.

Demographics
Age
Women vs men
Women <age of 50 years vs women
zage 50 years
Users of contraceptives vs non-users
among women $\leq 50$ years
BMI
Smokers vs non-smokers
Vitamin D metabolites
Total serum $25(\mathrm{OH}) \mathrm{D}$
Directly measured free $25(\mathrm{OH}) \mathrm{D}$
Calculated free $25(\mathrm{OH}) \mathrm{D}$
1,25(OH) ${ }_{2} \mathrm{D}$
iPTH
Other laboratory parameters
Testosterone (men only)
Estradiol (women only)
SHBG
hsCRP
ALT
Creatinine
Albumin

\begin{tabular}{c}
\hline Difference in serum DBP mean (s.D.) (mg/L) \\
\hline $265.4 \pm 87.8$ vs $245.0 \pm 71.5$ \\
$269.3 \pm 93.0$ vs $250.5 \pm 62.6$ \\
$328.5 \pm 122.9$ vs $261.0 \pm 85.3$ \\
$261.1 \pm 59.4$ vs $252.7 \pm 79.7$ \\
\end{tabular}

\begin{tabular}{|c|c|}
\hline Correlation with serum DBP & $P$-value \\
\hline \multirow[t]{4}{*}{$r=-0.068$} & 0.115 \\
\hline & 0.005 \\
\hline & 0.116 \\
\hline & 0.023 \\
\hline \multirow[t]{2}{*}{$r=-0.107$} & 0.013 \\
\hline & 0.613 \\
\hline$r=0.192$ & $<0.001$ \\
\hline$r=0.049$ & 0.225 \\
\hline$r=-0.452$ & $<0.001$ \\
\hline$r=0.144$ & 0.001 \\
\hline$r=-0.149$ & $<0.001$ \\
\hline$r=-0.062$ & 0.265 \\
\hline$r=-0.046$ & 0.532 \\
\hline$r=0.268$ & $<0.001$ \\
\hline$r_{\mathrm{s}}=0.102$ & 0.017 \\
\hline$r=-0.035$ & 0.421 \\
\hline$r=-0.043$ & 0.314 \\
\hline$r=-0.013$ & 0.762 \\
\hline
\end{tabular}

1,25(OH) 2 , 1,25-dihydroxy vitamin D; 25(OH)D, 25-hydroxy vitamin D; ALT, alanine aminotransferase; BMI, body mass index; DBP, vitamin D binding protein; HRT, hormone replacement therapy; hsCRP, highly sensitive c-reactive protein; iPTH, intact parathyroid hormone; $r$, Pearson correlation coefficient; $r_{\mathrm{s}}$, Spearman correlation coefficient; SHBG, sexual hormone binding globulin.

\section{Discussion}

We measured free $25(\mathrm{OH}) \mathrm{D}$ and DBP in serum in 540 healthy blood donors during 12 months to determine if the variation in total serum $25(\mathrm{OH}) \mathrm{D}$ with season is followed by a concomitant variation in free 25(OH)D. We found that directly measured free serum $25(\mathrm{OH}) \mathrm{D}$ was highly correlated with total serum 25(OH)D and followed the same seasonal variation, whereas the serum concentrations of DBP and albumin were stable. The fluctuation in free $25(\mathrm{OH}) \mathrm{D}$ was only marginally damped with an increase in the percentage of free $25(\mathrm{OH}) \mathrm{D}$ in participants with vitamin $\mathrm{D}$ deficiency and during the winter months, reflecting DBP ability to act as a reservoir for $25(\mathrm{OH}) \mathrm{D}$. Our findings of stable concentrations of serum DBP during the year are supported by one earlier study from 1981 (17).

The free hormone hypothesis states that proteinbound hormones are inactive and that only the free unbound fraction of a hormone can enter the cells and exert its biological effects $(18,19)$. In the case of vitamin $\mathrm{D}$, the pro-hormone $25(\mathrm{OH}) \mathrm{D}$ must enter the cells to be $\alpha$-hydroxylated to $1,25(\mathrm{OH})_{2} \mathrm{D}$. In the kidney, the intracellular uptake of $25(\mathrm{OH}) \mathrm{D}$ mainly occurs by megalin-mediated endocytosis of $25(\mathrm{OH}) \mathrm{D}$ bound to DBP and the uptake of $25(\mathrm{OH}) \mathrm{D}$ is thus facilitated by $\mathrm{DBP}$ (20). Megalin expression has also been found in other tissues such as the mammary glands, parathyroid gland, epididymis, lung and the placenta (21). Most other tissues are however dependent on the direct diffusion of the free unbound vitamin D forms through the cell wall and data suggest that DBP may actually have an inhibitory effect on $25(\mathrm{OH}) \mathrm{D}$ uptake here $(7,22)$. The seasonal variation in the concentration of free $25(\mathrm{OH}) \mathrm{D}$ shown in this study may thus have importance especially for extra-renal tissues, such as the immune cells.

When comparing directly measured free $25(\mathrm{OH}) \mathrm{D}$ with calculated free $25(\mathrm{OH}) \mathrm{D}$, we found that the directly measured concentration was significantly lower than the calculated, a finding supported by earlier studies (15). Directly measured free $25(\mathrm{OH}) \mathrm{D}$ also showed a stronger correlation with serum iPTH, indicating that directly measured free $25(\mathrm{OH}) \mathrm{D}$ more adequately reflects the biologic activity of vitamin $\mathrm{D}$ compared with the calculated free $25(\mathrm{OH}) \mathrm{D}$. The same findings and conclusion were reported by Schwartz and coworkers in an earlier study (10). In addition, we found that directly measured $25(\mathrm{OH}) \mathrm{D}$ better reflected DBP's ability to moderate the variation in free $25(\mathrm{OH}) \mathrm{D}$ by increasing the percentage of free $25(\mathrm{OH}) \mathrm{D}$ in situations of vitamin $\mathrm{D}$ deficiency

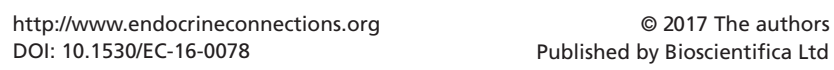


and decreasing it in times of abundance. Based on these results, we consider the use of directly measured free $25(\mathrm{OH}) \mathrm{D}$ to be of greater value than the calculated free $25(\mathrm{OH}) \mathrm{D}$. The discrepancies found between calculated and directly measured free $25(\mathrm{OH}) \mathrm{D}$ may be explained by that the affinity of $25(\mathrm{OH}) \mathrm{D}$ for DBP and albumin is not constant but varies depending on access to $25(\mathrm{OH}) \mathrm{D}$ and between individuals.

In the present study, the participants were Caucasians, ethnically homogenous and without any conditions known to affect the levels of DBP. Thus, the variation in the serum concentration of DBP was small.

Directly measured free $25(\mathrm{OH}) \mathrm{D}$ was strongly correlated with total $25(\mathrm{OH}) \mathrm{D}$, and the negative association with serum iPTH was comparable between the directly measured and total $25(\mathrm{OH}) \mathrm{D}$. Similar to our previous report on total $25(\mathrm{OH}) \mathrm{D}$, directly measured $25(\mathrm{OH}) \mathrm{D}$ was positively associated with parameters reflecting the UV-B exposure, such as the UV-B irradiance during the sampling month, sun holidays and sun bed use (16). Based on this, we found no strong advantages in measuring free $25(\mathrm{OH}) \mathrm{D}$ instead of total $25(\mathrm{OH}) \mathrm{D}$ to evaluate the vitamin D status clinically.

The current study confirms the results of earlier studies with higher serum concentrations of DBP in women and in users of oral contraceptives and hormone replacement therapy, but we found no association between DBP and the levels of sex hormones in serum (23). Instead, we found that serum DBP was independently and positively associated with serum SHBG after adjusting for sex, age, BMI, estrogen use and levels of sex hormones. Both DBP and SHBG are proteins known to be induced by estrogens (24). Our findings, however, suggest a common regulatory pathway for DBP and SHBG, beyond the sex hormones.

Several earlier studies have reported a negative association between total serum 25(OH)D and BMI (25). We found that increasing BMI was associated with lower levels of total $25(\mathrm{OH}) \mathrm{D}$, free $25(\mathrm{OH}) \mathrm{D}$ and $\mathrm{DBP}$, but on the other hand, with an increased percentage of free $25(\mathrm{OH}) \mathrm{D}$. The majority of the individuals in this cohort were however of normal weight $(60.7 \%)$ and only a minority were obese $(6.3 \%)$.

The present study has some limitations. Blood donors are a selected population of healthy individuals, and the results of the study may therefore not be representative of the general Swedish population. Gothenburg is situated at northern latitude, where the UV-B irradiance is too low during the winter months to allow the photolysis of vitamin D. As a result, the study may not be representative for populations living at southern latitudes. The measuring of free hormone concentrations has difficulties. The percentage of total $25(\mathrm{OH}) \mathrm{D}$, which exists in free form is very low, and the assay needs to be highly sensitive and specific to avoid cross-reactivity. Furthermore, the relationship between the free fraction and the proteinbound fraction may not be the same in in vitro as in vivo. The method used to measure free $25(\mathrm{OH}) \mathrm{D}$ in the current study needs further evaluation. Total $25(\mathrm{OH}) \mathrm{D}$ was measured with CLIA and not with the gold standard method liquid chromatography-mass spectrometry (LC-MS/MS). Serum DBP was assessed with ELISA using a monoclonal antibody specific for DBP. Recent studies have found that this method has problems detecting the DBP variant GC1f, which is common in populations of African descent. In the present study, no assessment of DBP genotype was done. The study population was however of European ancestry, where the GC1f genotype is rare, so the use of a monoclonal ELISA should not have had any great impact on our results. Another study limitation was that serum estrogen in the premenopausal women was not measured on a standardized day of the menstrual cycle.

\section{Conclusions}

Directly measured free $25(\mathrm{OH}) \mathrm{D}$ in serum was strongly correlated with total $25(\mathrm{OH}) \mathrm{D}$ and followed the same seasonal variation, whereas the serum concentrations of DBP and albumin were stable during the year. The variation in directly measured free $25(\mathrm{OH}) \mathrm{D}$ was however damped with an increase in the percentage of free $25(\mathrm{OH}) \mathrm{D}$ in situations of vitamin $\mathrm{D}$ deficiency and a decrease in vitamin $\mathrm{D}$ abundance. Both directly measured and total $25(\mathrm{OH}) \mathrm{D}$ were negatively correlated with serum iPTH, but calculated free $25(\mathrm{OH}) \mathrm{D}$ was only weakly associated with iPTH. Serum DBP was higher in women and estrogen users and independently associated with SHBG.

\footnotetext{
Declaration of interest

The authors declare that there is no conflict of interest that could be
} perceived as prejudicing the impartiality of the research reported.

\section{Funding}

This work was supported by the Swedish Cancer Society, the Swedish Research Council, LUA/ALF Funding at Sahlgrenska University Hospital, the Swedish Pain Foundation (SSF) and the Swedish Society of Medicine. http://www.endocrineconnections.org DOI: 10.1530/EC-16-0078
(C) 2017 The authors Published by Bioscientifica Ltd
This work is licensed under a Creative Commons Attribution-NonCommercial-NoDerivs 4.0 International License. 


\section{Acknowledgements}

The authors wish to thank all the blood donors who participated in the study. They also wish to thank Ann-Sofie Johansson Fällgren and coworkers at the Department of Clinical Chemistry at Sahlgrenska University Hospital.

\section{References}

1 Holick MF. Vitamin D status: measurement, interpretation, and clinical application. Annals of Epidemiology 200919 73-78. (doi:10.1016/j.annepidem.2007.12.001)

2 Gomme PT \& Bertolini J. Therapeutic potential of vitamin D-binding protein. Trends in Biotechnology 200422 340-345. (doi:10.1016/j. tibtech.2004.05.001)

3 Bhan I, Powe CE, Berg AH, Ankers E, Wenger JB, Karumanchi SA \& Thadhani RI. Bioavailable vitamin D is more tightly linked to mineral metabolism than total vitamin $\mathrm{D}$ in incident hemodialysis patients. Kidney International 201282 84-89. (doi:10.1038/ki.2012.19)

4 Powe CE, Ricciardi C, Berg AH, Erdenesanaa D, Collerone G, Ankers E, Wenger J, Karumanchi SA, Thadhani R \& Bhan I. Vitamin D-binding protein modifies the vitamin D-bone mineral density relationship. Journal of Bone and Mineral Research 201126 1609-1616. (doi:10.1002/ jbmr.387)

5 Delanghe JR, Speeckaert R \& Speeckaert MM. Behind the scenes of vitamin D binding protein: more than vitamin D binding. Best Practice and Research: Clinical Endocrinology and Metabolism 201529 773-786. (doi:10.1016/j.beem.2015.06.006)

6 Speeckaert M, Huang G, Delanghe JR \& Taes YE. Biological and clinical aspects of the vitamin D binding protein (Gc-globulin) and its polymorphism. Clinica Chimica Acta 2006372 33-42. (doi:10.1016/j. cca.2006.03.011)

7 Chun RF, Peercy BE, Orwoll ES, Nielson CM, Adams JS \& Hewison M. Vitamin D and DBP: the free hormone hypothesis revisited. Journal of Steroid Biochemistry and Molecular Biology 2014144 132-137. (doi:10.1016/j.jsbmb.2013.09.012)

8 Bikle DD, Gee E, Halloran B, Kowalski MA, Ryzen E \& Haddad JG. Assessment of the free fraction of 25-hydroxyvitamin D in serum and its regulation by albumin and the vitamin D-binding protein. Journal of Clinical Endocrinology and Metabolism 198663 954-959. (doi:10.1210/jcem-63-4-954)

9 Schwartz JB, Lai J, Lizaola B, Kane L, Weyland P, Terrault NA, Stotland N \& Bikle D. Variability in free $25(\mathrm{OH})$ vitamin D levels in clinical populations. Journal of Steroid Biochemistry and Molecular Biology 2014144 156-158. (doi:10.1016/j.jsbmb.2013.11.006)

10 Schwartz JB, Lai J, Lizaola B, Kane L, Markova S, Weyland P, Terrault NA, Stotland N \& Bikle D. A comparison of measured and calculated free $25(\mathrm{OH})$ vitamin D levels in clinical populations. Journal of Clinical Endocrinology and Metabolism 201499 1631-1637. (doi:10.1210/jc.2013-3874)

11 Aloia J, Mikhail M, Dhaliwal R, Shieh A, Usera G, Stolberg A, Ragolia L \& Islam S. Free 25(OH)D and the vitamin D paradox in African Americans. Journal of Clinical Endocrinology and Metabolism 2015100 3356-3363. (doi:10.1210/JC.2015-2066)

12 Powe CE, Evans MK, Wenger J, Zonderman AB, Berg AH, Nalls M, Tamez H, Zhang D, Bhan I, Karumanchi SA, et al. Vitamin D-binding protein and vitamin D status of black Americans and white
Americans. New England Journal of Medicine 2013369 1991-2000. (doi:10.1056/NEJMoa1306357)

13 Henderson CM, Lutsey PL, Misialek JR, Laha TJ, Selvin E, Eckfeldt JH $\&$ Hoofnagle AN. Measurement by a novel LC-MS/MS methodology reveals similar serum concentrations of vitamin D-binding protein in blacks and whites. Clinical Chemistry 201662 179-187. (doi:10.1373/ clinchem.2015.244541)

14 Bouillon R. Free or total 25OHD as marker for vitamin D status? Journal of Bone and Mineral Research 201631 1124-1127. (doi:10.1002/ jbmr.2871)

15 Nielson CM, Jones KS, Chun RF, Jacobs JM, Wang Y, Hewison M, Adams JS, Swanson CM, Lee CG, Vanderschueren D, et al. Free 25-hydroxyvitamin D: impact of vitamin D binding protein assays on racial-genotypic associations. Journal of Clinical Endocrinology and Metabolism 2016101 2226-2234. (doi:10.1210/jc.2016-1104)

16 Klingberg E, Olerod G, Konar J, Petzold M \& Hammarsten O. Seasonal variations in serum 25-hydroxy vitamin D levels in a Swedish cohort. Endocrine 201549 800-808. (doi:10.1007/s12020-015-0548-3)

17 Bouillon R, Van Assche FA, Van Baelen H, Heyns W \& De Moor P. Influence of the vitamin D-binding protein on the serum concentration of 1,25-dihydroxyvitamin D3. Significance of the free 1,25-dihydroxyvitamin D3 concentration. Journal of Clinical Investigation 198167 589-596. (doi:10.1172/JCI110072)

18 Vermeulen A, Verdonck L \& Kaufman JM. A critical evaluation of simple methods for the estimation of free testosterone in serum. Journal of Clinical Endocrinology and Metabolism 199984 3666-3672. (doi:10.1210/jcem.84.10.6079)

19 Mendel CM. Modeling thyroxine transport to liver: rejection of the 'enhanced dissociation' hypothesis as applied to thyroxine. American Journal of Physiology 1989257 E764-E771.

20 Nykjaer A, Dragun D, Walther D, Vorum H, Jacobsen C, Herz J, Melsen F, Christensen EI \& Willnow TE. An endocytic pathway essential for renal uptake and activation of the steroid 25-(OH) vitamin D3. Cell 199996 507-515. (doi:10.1016/S00928674(00)80655-8)

21 Lundgren S, Carling T, Hjalm G, Juhlin C, Rastad J, Pihlgren U, Rask L, Akerstrom G \& Hellman P. Tissue distribution of human gp330/megalin, a putative $\mathrm{Ca}(2+)$-sensing protein. Journal of Histochemistry and Cytochemistry 199745 383-392. (doi:10.1177/0022 15549704500306

22 Zella LA, Shevde NK, Hollis BW, Cooke NE \& Pike JW. Vitamin D-binding protein influences total circulating levels of 1,25-dihydroxyvitamin D3 but does not directly modulate the bioactive levels of the hormone in vivo. Endocrinology 2008149 3656-3667. (doi:10.1210/en.2008-0042)

23 Moller UK, Streym S, Jensen LT, Mosekilde L, Schoenmakers I, Nigdikar S \& Rejnmark L. Increased plasma concentrations of vitamin $\mathrm{D}$ metabolites and vitamin $\mathrm{D}$ binding protein in women using hormonal contraceptives: a cross-sectional study. Nutrients 20135 3470-3480. (doi:10.3390/nu5093470)

24 Simo R, Saez-Lopez C, Barbosa-Desongles A, Hernandez C $\&$ Selva DM. Novel insights in SHBG regulation and clinical implications. Trends in Endocrinology and Metabolism 201526 376-383. (doi:10.1016/j.tem.2015.05.001)

25 Karlsson T, Osmancevic A, Jansson N, Hulthen L, Holmang A \& Larsson I. Increased vitamin D-binding protein and decreased free $25(\mathrm{OH}) \mathrm{D}$ in obese women of reproductive age. European Journal of Nutrition 201453 259-267. (doi:10.1007/s00394-013-0524-8)

Received in final form 20 December 2016

Accepted 8 February 2017

Accepted Preprint published online 8 February 2017 http://www.endocrineconnections.org DOI: 10.1530/EC-16-0078 (c) 2017 The authors Published by Bioscientifica Ltd
This work is licensed under a Creative Commons Attribution-NonCommercial-NoDerivs 4.0 International License. 